\title{
Civil society participation in global governance: Insights from climate politics
}

\author{
TOBIAS BÖHMELT, VALLY KOUBI \& THOMAS BERNAUER \\ ETH Zurich, Switzerland
}

\begin{abstract}
A somewhat unique feature of the global climate negotiations is that most governments allow representatives of civil society organizations to be part of their national delegation. It remains unclear, however, why states grant this access in the first place. While there are likely to be benefits from formally including civil society, there are also substantial costs stemming from constraints on sovereignty. In light of this tradeoff, the paper argues for a 'contagion' effect in order to explain this phenomenon. States, which are more central to the broader network of global governance, are more likely to be informed of and influenced by other states' actions and policies toward civil society. In turn, more central governments are likely to include civil society actors if their counterparts do so as well. This argument is tested with data on the participation of civil society organizations in national delegations to global climate negotiations between 1995 and 2005. To further uncover the underlying mechanisms, the paper also provides an analysis of survey data collected at the recent UNFCCC negotiations in Durban in 2011.
\end{abstract}

Keywords: civil society; climate change; global governance; social network analysis

Paper to be presented at the annual meeting of the European Political Science Association, Barcelona, Spain, June 20-22, 2013.

\section{Acknowledgment}

We acknowledge financial support from the NCCR's (National Center of Competence in Research) project on 'Challenges to Democracy in the 21st Century' (http://www.nccrdemocracy.uzh.ch/). 


\section{Introduction}

Civil society organizations (CSOs) ${ }^{1}$ have become increasingly important in world politics over the past few decades. Academic interest in the drivers of this development has grown accordingly, with a strong focus on policy areas such as human rights and environmental politics where the involvement of CSOs is particularly pronounced (e.g., Weiss \& Gordenker 1996; Charnovitz 1997; Raustiala 1997; Clark et al. 1998; Scholte 2004; Betsill 2006; Bernauer \& Betzold 2012; Bernauer et al. 2013). Much of this existing research on civil society in global governance concentrates on whether and how CSOs are able to influence international policy-making and its outcomes (e.g., Paterson 1996; Corell \& Betsill 2001; Gulbrandsen \& Andresen 2004; Betsill \& Corell 2001; 2008; Betsill 2006). However, one aspect of this issue has received rather little attention to date: why do governments frequently include CSOs formally in international policy-making?

This question is fundamental because most scholars agree that states were and generally still are in control of international policy-making processes. Why, to what extent, and in what form could they be interested in relinquishing some control over policy-making? On the one hand, the overwhelming majority of global governance sectors, e.g., trade liberalization, monetary policy, banking regulation, or security policy efforts, is strictly intergovernmental (Thomann 2007). On the other hand, the participation of CSOs in international politics exists in a few areas, $^{2}$ and in particular the policy-making process in global climate policy is characterized by the presence of numerous civil society observers and an impressive number of CSO representatives that are formally included in states' negotiation delegations. For

\footnotetext{
${ }^{1}$ Following Steffek \& Nanz (2007: 28f; see also Castiglione 1998; Keck \& Sikkink 1998), we consider as civil society all those actors (groups) that pursue interests in global governance, but do not belong to or are affiliated with official governmental and/or state entities. This approach possibly employs the broadest definition by also including business associations or corporations (see also Biermann \& Gupta 2011, 1856; Bernstein 2005: 148; Haas 1999: 103).

${ }^{2}$ For instance, one might think of the International Labor Office with its tripartite corporatist representation of government, business, and labor. As elaborated below, however, we focus on CSOs' membership in states' delegations at the global climate negotiations, which we define as formal participation.
} 
example, during the 2011 round of the United Nations Framework Convention on Climate Change (UNFCCC) negotiations, about the same number of civil society and government representatives participated; more than $70 \%$ of the 193 countries involved formally granted at least one CSO representative access to their national delegation; and about 18\% of all members of national delegations were CSO representatives (see Böhmelt 2013).

The formal inclusion of CSOs in national delegations generally offers greater opportunities for these actors to influence governmental decision-making (Weiss \& Gordenker 1996; Raustiala 1997; Gulbrandsen \& Andresen 2004: 59; Steffek \& Nanz 2007: 11; Thomann 2007). ${ }^{3}$ This stems from the fact that CSOs are then not excluded from the unofficial sessions between governments, which are usually the decisive places for drafting conference declarations or treaties (Clark et al. 1998: 18). Hence, they actively participate in informal backdoor diplomacy, receive official state documents, and are able to present proposals (Raustiala 1997; Gulbrandsen \& Andresen 2004). Gulbrandsen \& Andresen (2004: 73) conclude accordingly that CSOs are likely to 'have the most far-reaching influence on [...] negotiations if they foster ways to work closely and collaboratively with key negotiators.'

While it thus seems apparent why CSOs would welcome their inclusion in national delegations, it is more difficult to understand why governments may want to grant CSOs access in the first place. ${ }^{4}$ First and foremost, including CSOs is likely to constrain governmental autonomy or sovereignty, which we define as 'the institutionalization of public

\footnotetext{
${ }^{3}$ We do not imply that participating in state delegations is the exclusive avenue for exerting influence. We do also not state that access to delegations always and necessarily induces access to higher levels of decision-making. We claim, however, that it is one potential (and perhaps a sufficient) avenue for doing so. In consistence with that, Biermann \& Gupta (2011: 1857ff) emphasize that the inclusion of civil society actors in international negotiations constitutes an important facet of those negotiations, while Gulbrandsen (2008) is particularly interested in the 'privileged access' of non-governmental actors (see also Sell \& Prakash 2004: 151).

${ }^{4}$ Note that existent approaches such as the boomerang model (Keck \& Sikkink 1998) 'privilege the agency of NGOs and do not consider why states would sometimes institutionalize' the relationship to civil society actors (Vabulas 2011: 1). That being said, considering also supply-side arguments would arguably provide a more comprehensive picture. However, this is beyond the scope of our paper and actually prevented due to data limitations. We will return to this issue in the conclusion.
} 
authority within mutually exclusive jurisdictional domains’ (Ruggie 1986: 143), in the sense that this cuts into the traditional prerogative of the nation-state to negotiate international agreements with other governments (Clark et al. 1998; Clark 1995; Stasavage 2004). ${ }^{5}$ Consequently, states determine which non-governmental actors may participate and CSOs are often denied access to policy-making processes or are only allowed to participate as observers, i.e., they are not permitted to express their positions and participate in decisionmaking during the negotiating process per se (Weiss \& Gordenker 1996; Raustiala 1997; Thomann 2007).

In light of this, it is rather puzzling why governments formally include CSOs, since sovereignty is normally seen as one of the most valuable goods for states (see Biermann \& Gupta 2011: 1856). Nonetheless, the literature highlights two motivations of governments to involve CSOs (Grant \& Keohane 2005; Biermann \& Gupta 2011; Böhmelt 2013; for an overview, see, e.g., Bernauer \& Betzold 2012). First, states may expect to obtain useful information and expertise that they lack regarding the issue at hand (Raustiala 1997; see also Betsill \& Corell 2001; 2008; Biermann \& Pattberg 2008). The second motivation focuses on legitimacy: governments may opt for civil society participation as a means to mitigate the 'democracy deficit' and/or to enhance the legitimacy of global governance (e.g., Bernstein 2005; Grant \& Keohane 2005; Betsill \& Corell 2008; Steffek \& Ferretti 2009; Biermann \& Gupta 2011; Keohane 2011; Dryzek 2012).

In this paper, we focus on the legitimacy argument, which we combine with a social network perspective to explain variation in CSO inclusion in global climate governance. We argue that governments are a priori hesitant to formally include CSOs in international policymaking processes. However, governments are embedded in broader networks of interstate

\footnotetext{
${ }^{5}$ Governments may try and avoid this dilemma by including CSOs that share the same interests with them. But doing so is unlikely to have the desired legitimacy increasing effect and, hence, the dilemma remains.
} 
relations. States more strongly embedded in these networks benefit from a higher flow of information therein, and they are then more likely to be influenced by the practices of other governments with respect to CSOs. We ultimately argue that states are more likely to formally include CSOs in order to avoid a potential legitimacy advantage of their counterparts and to enhance domestic legitimacy if the following two conditions apply: first, if they are more central to the global governance network and, second, if other states formally include CSOs as well.

We test this hypothesis with data on formal CSO inclusion in national delegations to the UNFCCC negotiations between 1995 and 2005. Quantitative statistical analyses offer strong support for the hypothesized contagion effect. Additional evidence from a survey of 50 national delegation representatives to the 2011 UNFCCC conference in Durban suggests that legitimacy considerations are likely to be one of the main causal mechanisms underlying the quantitative findings, although we also find evidence for states' concerns over sovereignty. The academic and practical relevance of our research extends beyond the specific case of climate policy, in the sense that this work contributes to 'identifying sources and mechanisms that can contribute to enhanced accountability and legitimacy of governance arrangements' (Biermann \& Gupta 2011: 1856; Kingsbury 2007; Mason 2008).

\section{Social networks, legitimacy, and civil society participation: Theoretical argument}

We develop our theoretical argument by first elaborating on social networks and how they may affect the evolution of shared norms and practices through information flows. We then discuss the reasons for why states may want to grant CSOs access to global governance efforts more thoroughly, with an emphasis on the legitimacy enhancing effects of such an involvement. In a third step, we connect the social network and civil society arguments to hypothesize that governments, which are more central to the global governance network, are 
more likely to include civil society actors in response to other governments adopting this practice.

Social networks: The role of ties and centrality

In general, a social network is characterized by a set of actors and the relations between them (e.g., Borgatti et al. 2009; Hafner-Burton et al. 2009; Maoz 2010; Bodin \& Prell 2011; Ward et al. 2011). Actors can be individuals, groups of people, or states that are connected by specific types of relationships. Each kind of resource exchange is considered a network relation and actors experiencing such a relation are said to maintain a tie (or link). The strength of a tie may range from weak to strong, depending on the quantity, quality, or frequency of exchanges between actors. Patterns of who is tied to whom, and how, reveal the structure of the underlying network: they show how resources flow between actors and how these are interconnected in a network. Mutual memberships of two states in intergovernmental organizations (IGOs), which will be of particular interest in this paper, provide one example for a tie linking two countries. These ties can be of direct or indirect nature. Direct links are connections that link two countries directly. States may also share indirect links, i.e., ties to one or more than one intermediary that connect two countries in the network. Direct and indirect links, therefore, connect a country to other states and determine the density, i.e., the cohesiveness of a social network as measured by the number and strength of links.

Ties in social networks, both direct and indirect, facilitate the transmission of information about interests and intentions, and they tend to promote a common understanding (Dorussen \& Ward 2008: 192f). Links that are shorter and denser enable actors to convey information at lower cost, with more precision, and faster. Denser social networks can thus help reduce uncertainty, increase trust, and facilitate the development of mutually accepted norms (Ward 
2006: 151ff; Hafner-Burton \& Montgomery 2006; Dorussen \& Ward 2008: 194f; HafnerBurton et al. 2009: 569; Leifeld \& Schneider 2012: 3; Ward \& Cao 2012). In other words, interaction through network ties influences the behavior of actors by 'endowing some with greater social power and by shaping common beliefs about behavior' (Hafner-Burton \& Montgomery 2006: 8).

Against this background, Ward (2006: 151f) and others (e.g., Bodin \& Prell 2011; for an overview, see Hafner-Burton et al. 2009) emphasize that countries with more numerous ties to other parties are extensively involved in relationships with the latter. This involvement makes states more central in a network. Greater network centrality increases opportunities for knowledge sharing and frequent encounters provide prospects for face-to-face contact that facilitate the diffusion of ideas, norms, and practices. In international politics, on which this paper focuses, IGO networks can thus form the basis for normative influence between states (Torfason \& Ingram 2010). For example, von Stein (2008) finds that states' level of centrality in the global IGO network has a positive effect on their participation in international climate agreements. The recent literature also shows that mutual IGO membership affects domestic policy choices, since connections in the network of IGOs can provide countries with information that fosters policy-learning and socialization (e.g., Cao 2009; 2010; HafnerBurton et al. 2008)

\section{Legitimacy promoting effects of formal civil society involvement}

As noted above, states should be generally unwilling to involve CSOs in global governance as this imposes constraints on government behavior (Clark 1995; Stasavage 2004). In the words of Clark et al. (1998: 29), 'while governments have agreed to a certain level of NGO [civil society] involvement at the international level, they still bar NGO [civil society] participation in procedures or issues that in some way restrict state sovereignty.' Such restrictions and 
constraints are particularly pronounced if CSOs are formally included in delegations at international negotiations. Even if governments carefully select civil society representatives, giving CSOs a 'seat at the table' may result in considerable costs, since these use the improved opportunity for direct access to influence a state’s bargaining position in ways that could be undesirable from the government's point of view. They may also openly voice dissent vis-à-vis the government's position at the bargaining table and, hence, weaken a state's negotiating position. Finally, the possibility exists that they leak confidential information to the press and the public.

The literature highlights two potential reasons why states might be interested in formally involving CSOs in global governance efforts nevertheless. First, governments may expect to obtain useful information and expertise (Raustiala 1997; see also Betsill \& Corell 2001; 2008; Biermann \& Pattberg 2008). Raustiala (1997), for example, notes that civil society can help governments to obtain policy-relevant information at low cost, given the high level of uncertainty and complexity that characterizes environmental issues. However, recent research does not find support for the empirical implications of the information argument. For example, Böhmelt (2013) observes that civil society actors are more often included in delegations of countries with a higher bureaucratic quality, which '[...] are least in need of expertise and information provision.' Others have challenged the knowledge argument on conceptual grounds: Bernauer \& Betzold (2012: 64) argue that the 'existing research offers episodic, but not systematic and strong empirical evidence that more civil society participation has contributed to more effective agreements.'

Second, governments may want to formally include CSOs due to concerns over legitimacy. Legitimacy commonly describes 'the state or quality of being legitimate, i.e., of being in accord with established legal norms and requirements, or conforming to recognized principles or accepted rules and standards of behavior. Core elements of the concept of legitimacy are 
the acceptance and justification of authority. Acceptance relates to the way in which rules or institutions are accepted by a community as being authoritative. Justification relates to the reasons that justify the authority of certain rules or institutions’ (Biermann \& Gupta 2011: 1858; see also Bernstein 2005; Keohane 2011). ${ }^{6}$ In the words of Lipset (1983: 64), 'legitimacy involves the capacity of a political system to engender and maintain the belief that existing political institutions are the most appropriate and proper ones for the society.'

Hence, states may opt for civil society participation as a means to enhance legitimacy of global governance at the international but also the national level (Bernauer \& Betzold 2012: 63; see also, e.g., Grant \& Keohane 2005; Bernstein 2005; Betsill \& Corell 2008; Steffek \& Ferretti 2009; Biermann \& Gupta 2011; Dryzek 2012). There is a widespread perception among electorates in many countries that international politics suffer from a lack of legitimacy and/or are characterized by a 'democratic deficit’ (e.g., Nye 2001; Bernstein 2005; Steffek \& Nanz 2007; Steffek \& Ferreti 2009). Many observers of global governance thus call for 'opening up the intergovernmental system to institutionalized balanced involvement of non-state actors' (Biermann \& Gupta 2011: 1862). According to this logic, granting CSOs access to national delegations should improve political responsiveness, transparency, or (democratic) accountability, and ultimately legitimacy in the sense of international and domestic public support (Clark et al. 1998: 2; see also Gulbrandsen \& Andresen 2004: 59f; Grant \& Keohane 2005; Steffek \& Nanz 2007: 3; Steffek \& Ferreti 2009; Dombrowski 2010; Biermann \& Gupta 2011: 1858; Bernauer \& Betzold 2012). ${ }^{7}$

\footnotetext{
${ }^{6}$ In this paper we concentrate on external legitimacy, i.e., the acceptance of a rule by non-members or non-participants (Biermann \& Gupta 2011: 1858).

${ }^{7}$ In other words, we focus on legitimacy gains due to the formal inclusion of CSOs both at the international level, i.e., Putnam's (1988: 436) first stage of the two-level game and his second stage that deals with domestic-level interests. In fact, CSOs are usually mass membership organizations. As representatives of voters, CSOs then shape public opinion and signal electoral (i.e., domestic) preferences to policymakers. Further, CSOs may signal voter preferences even in relatively closed negotiations through outsider strategies such as protests, demonstrations, or other types of direct action outside the negotiation forum. Therefore, the formal inclusion of CSOs in state delegations is not only
} 
In fact, Hass (1999: 103) and Bernstein (2005: 148) explicitly state that non-governmental organizations can increase legitimacy of global policy-making via their inclusion in states' negotiation delegations. Bernauer \& Betzold (2012: 63) conclude that 'more civil society participation will then, presumably, result in [...] more legitimate global environmental agreements.' For empirical evidence of the legitimizing force of civil society groups, Dellas (2011) and Schouten \& Glasbergen (2011) demonstrate that civil society groups could enhance legitimacy via their participation in the decision-making processes of the UN Commission on Sustainable Development or the Roundtable on Sustainable Palm Oil, respectively. Moreover, consider the following example of the Chinese delegation at the United Nations Conference on Environment and Development in 1992. According to Economy (2004: 126), the Chinese delegation was ‘embarrassed’ by its lack of civil society representation as compared to other countries and perceived this as a disadvantage in legitimacy and public support at the national and international level. This case also shows, however, that concerns over legitimacy alone may not necessarily be enough - the Chinese delegation became only aware of its 'disadvantage' when realizing what other states do. ${ }^{8}$

\section{Network centrality and civil society inclusion}

The existing evidence seems to favor the legitimacy argument and we thus focus on this incentive of states in the following for combining it with the network perspective. In short, we argue for a contagion effect to the extent that states, which are more central to the broader network of global governance, are more likely to be informed of and influenced by other states' actions and policies toward civil society and may then react upon these.

driven by countries' interests to enhance legitimacy at the international but also the national level in order to increase the chances to 'sell' international agreements domestically.

${ }^{8}$ Note, however, that civil society and its formal inclusion in states’ negotiation delegations may not always or necessarily enhance legitimacy (e.g., Dryzek \& Stevenson 2011). In the words of Bernauer \& Betzold (2012: 64), 'we simply do not (yet) know whether civil society participation can promote public support [legitimacy] for global environmental policies.’ 
More specifically, consensual knowledge, the evolvement of norms, and ultimately the degree of centrality in a network can shape actors' behavior toward CSOs. If governments are well connected to other states, i.e., they experience a higher flow of communication in the overall state network due to a more central position, they are more aware of other countries' position and preferences toward civil society. However, we do not claim that a more central position per se increases the likelihood that states formally include CSOs. Instead, while assuming that states generally do have concerns over legitimacy and accountability (Bierman \& Gupta 2011; Bernauer \& Betzold 2012), we argue that they might value these concerns higher than those about governmental autonomy and sovereignty if two conditions are met. First, other countries demonstrate a 'positive behavior' toward CSOs by, e.g., granting them formally access and, second, a state is aware of this. In other words, the likelihood of formally including CSOs in a national delegation depends on the degree of the respective country's network centrality and the behavior of other governments vis-à-vis CSOs. Under those circumstances, states will be more likely to grant CSO representatives access if their counterparts do so as well in order to avoid potential legitimacy advantages of those counterparts and to enhance domestic legitimacy. This means that countries discount the loss of autonomy and put a higher value on legitimacy gains - however, only if other states do the same and if a state knows about this.

For illustrative purposes, consider the decisions of countries $i$ and $j$ in this respect. If $j$ decides to involve CSOs, $i$ has a stronger incentive to do the same for two closely related, but distinct reasons. First, $i$ learns that $j$ came to the conclusion that the advantages of including CSO may outweigh the costs. This reduces uncertainty for $i$ in respect to the costs and benefits of CSO inclusion and motivates inclusion of CSOs on the part of $i$. Second, CSO inclusion by $j$ but not by $i$ could become disadvantageous for $i$ both domestically and internationally. Domestically, CSOs in country $i$ are likely to use CSO inclusion by $j$ to urge 
the former to involve CSOs as well. Internationally, $i$ may also have to justify vis-à-vis $j$ and other states why it is not involving CSOs. At either level, however, given the definition and importance of legitimacy above, $j$ is likely to have a legitimacy advantage over $i$. Greater network centrality is important in this respect, since it leads to more information on government preferences and behavior traveling both ways: to the respective government, and from the latter to other governments. Hence, we formulate the main hypothesis as a contagion effect, i.e., states more central to the global governance network are more likely to formally include CSOs when other states do so. Conversely, states that are peripheral to the global governance network are unlikely to include CSOs even if other states in the network do so.

\section{Research design}

We first use a quantitative approach to examine whether the empirical evidence is consistent with the theoretical argument. This approach cannot, however, directly tell us whether legitimacy considerations and the tradeoff between sovereignty constraints and legitimacy gains are in fact the underlying driving force in governmental decisions on CSO involvement. To enhance confidence in our quantitative findings, we thus add insights from survey research conducted at the $17^{\text {th }}$ Conference of the Parties (CoP) of the UNFCCC in Durban in 2011.

\section{Dependent variable and methodology}

With regard to the quantitative analyses, the dependent variable measures whether a country included at least one CSO representative in its national delegation to a given CoP to the UNFCCC (1) or not (0). These panel data cover the time period from 1995 to 2011 (Böhmelt 2013). Consistent with the UNFCCC definition applied to participants in CoPs, our treatment of CSO representatives includes persons who are not employed or affiliated with a government/state or an inter-governmental organization but pursue interests in global climate 
politics (see also Steffek \& Nanz 2007). We merged these data on CSO inclusion to a data set whose unit of analysis is the directed country-dyad-year, e.g., the data include both the country-pair France-Brazil in 1998 and the country-pair Brazil-France in 1998. This data structure is necessary given the inherent directed logic of our theory: Brazil's inclusion of CSOs could affect the probability of France also including CSOs - and vice versa. Because we lack data for most of our covariates after 2005, the combined data set covers the time period 1995-2005. The statistical analysis uses probit regression models, since the dependent variable is dichotomous. Robust standard errors are clustered on each dyad to account for intra-group correlations or other forms of cross-section heterogeneity. The temporal dependencies are controlled by including a civil-society-years variable and different sets of cubic splines (Beck et al. 1998). This approach acknowledges that CSO inclusion might depend on corresponding choices in previous years.

\section{Main explanatory variables}

The main explanatory variables according to our argument are the behavior of other governments vis-à-vis CSOs and network centrality. With regard to the former, we use data on CSO inclusion by other countries as a proxy, taken from the same data source (Böhmelt 2013) as used for the dependent variable - however, now focusing on a state's counterpart in a dyad. To avoid potential problems with endogeneity, this variable Civil society - Dyadic counterpart is lagged by one year.

For network centrality, we consider a country's whole range and any strength of all ties to the entire IGO network (Hafner-Burton et al. 2009: 563f; Dorussen \& Ward 2008; Freeman et al. 1991) and calculate it in terms of the reduction in total information flow in the network that would occur if a respective state did not exist. Put differently, we focus on the degree to 
which the maximum flow between all unordered pairs of points depends on $i$ and it is calculated by,

$$
\text { Network centrality }=\sum_{j<k}^{n} \sum^{n} m_{j k}\left(x_{i}\right)
$$

where $i \neq k \neq j$, and $x_{i}$ is a node in the network, i.e., the state of interest in a directed dyad; $m_{j k}$ is the maximum flow of information or the strength of ties from country $x_{j}$ to another country $x_{k}$; consequently, $m_{j k}\left(x_{i}\right)$ is the maximum flow of information from $x_{j}$ to $x_{k}$ that passes through country $x_{i}$. It is calculated taking into account all actors of the network, i.e., all unordered pairs of states in the global governance network (see Freeman et al. 1991: 148). We use a standardized measure that ranges between 0 and 1 and follow Dorussen \& Ward (2008) in operationalizing ties between states via common IGO memberships.

The raw data for our network centrality variable were retrieved from Pevehouse et al. (2004). We then calculated the corresponding adjacency matrixes for each year in 1995-2005 and estimated the respective values on the network centrality variable for each country and year in every directed dyad. This operationalization also has practical reasons, as most IGOs are weakly institutionalized (Dorussen \& Ward 2008). Thus, in practice, we can ignore their (direct) influence as an intervening variable and an IGO then primarily serves as a vehicle that establishes ties between states through, e.g., the encounter of representatives in meetings and the working practices of the respective organization.

To estimate the interactive impact of Civil society - Dyadic counterpart and Network centrality, we multiply the two variables and simultaneously include the new variable in the models.

\section{Control variables}


The empirical models also include a range of covariates that help avoid omitted variable bias. Furthermore, considering alternative determinants of civil society inclusion also addresses possible selection effects, as only certain types of delegations are likely to consider the inclusion of CSOs. First, despite the lack of empirical support in previous research, we still control for the knowledge provision argument as discussed above by including an indicator for the quality of a country's public administration. We use data from the Political Risk Services Group’s (PRSG) International Country Risk Guide (Howell 2011). Specifically, we include an indicator that is based on expert assessments and uses a 0-4 scale, with higher values signifying a higher bureaucratic quality in a country.

Second, we also include the variable GDP per capita (In). With a view to the environmental Kuznets curve literature (Seleden \& Song 1994; Grossman \& Krueger 1995), wealthier societies are more interested in forms of environmental protection focusing on measures other than the traditional ones that reduce local pollution. Climate policy may thus be more salient than in poorer countries (Mendelsohn et al. 2006). This, in turn, can motivate governments of richer countries to include CSOs. However, more developed countries tend to be less vulnerable to climatic changes, which may reduce the political saliency of the climate issue and the pressure for including CSOs. Because our theoretical focus lies elsewhere, we are agnostic about the net impact of such income effects, but control for them. The data are taken from the World Bank Development Indicators.

Third, democracies, relative to non-democracies, are more likely to provide environmental public goods at the national level and are more inclined to cooperate in international environmental problem-solving efforts as well (e.g., Congleton 1992; Ward 2008). We use Polity IV data to measure democracy (Marshall \& Jaggers 2002), with the final variable ranging from -10 (full autocracy) to +10 (full democracy). 
Fourth, the literature leads us to expect that pollution levels will fall with the power of green civil society groups (see Bernauer et al. 2013; see also Cao \& Prakash 2012: 70; Ward \& Cao 2012: 6). Hence, CSOs may have more political clout domestically if they are more numerous and this could also affect our dependent variable of interest. We control for this effect by adding the number of national environmental NGOs registered in each country using data from the International Union for Conservation of Nature (Bernauer et al. 2013).

Finally, state delegations vary significantly in the number of involved delegation members. For example, the mean delegation size of the U.S. is about 71, while the Bahamas sent only two delegates to the CoPs on average. Since large countries are more likely to have larger delegations, we use the logged population size of a country to control for this. The data are taken from the World Bank Development Indicators. Similarly, 'big and important' countries might be more reluctant to accept constraints on their behavior that could result from CSO involvement. To account for this possibility, we include a dichotomous major power variable from the Correlates of War Project (Singer 1988).

\section{Empirical results}

Principle findings

We use multivariate probit analysis to estimate three models. The first model concentrates on the main explanatory variables, while it excludes the control items except those for temporal aspects. The second model includes only the control covariates. The third model considers both explanatory and control variables. Instead of reporting the probit coefficients in a standard form, we present simulated first difference estimates (King et al. 2000). The first difference, in this context, equals the change in probability of a country including CSO representatives that results from a change on a respective explanatory variable from the minimum to the maximum value, while holding all other covariates at their median value. 
Table 1 in here

We start with the control variables in Models 2-3. Most controls have a substantial and statistically significant influence on the dependent variable. Countries with a higher income, more democratic states, and countries with a larger population are more likely to include CSOs in their national delegations. When moving from the minimum to the maximum of Democracy, for instance, the probability of a country including CSOs increases by $19.5 \%$. Moreover, Major power and Domestic civil society negatively affect the probability of CSO inclusion. While the finding for the former variable is intuitively plausible, the latter might seem surprising. On average, the probability of CSO inclusion decreases by $17.5 \%$ as Domestic civil society grows from its minimum to its maximum value. One possible interpretation of this result relates to a 'democracy-civil society paradox' examined by Bernauer et al. (2013). These scholars argue that the marginal positive effect of civil society on international environmental cooperation decreases at high levels of democracy (see also Johnson \& Prakash 2007). Finally, the insignificant effect of Bureaucratic quality is consistent with previous studies that were unable to find robust evidence for the information provision argument.

With regard to the main explanatory variables and their interactive effect, note that we cannot interpret this directly (see Brambor et al. 2006). Thus, we computed the marginal effect of Civil society - Dyadic counterpart on our dependent variable along the values of Network centrality to allow for a substantive interpretation. Figure 1 depicts the results.

Figure 1 in here 
The likelihood of a state's CSO inclusion increases by about $5-7 \%$ if a state is very central in the global governance network and if the other country in the dyad under study included CSO representatives in its national delegation before. This finding supports our theoretical argument on the contagion effect that countries include CSOs to enhance legitimacy. Conversely, the evidence also shows that countries that are peripheral to the global governance network are unlikely to include CSO representatives even if other countries in the network do. This finding is supported by the insignificant marginal effects of Civil society Dyadic counterpart at low to moderate values of Network centrality. In the same vein, countries that are central to the network do not include CSOs if other countries do not include CSOs either. Put differently, even if a country is well connected in the network and, thus, is able to gain information regarding its counterparts' intentions and preferences toward CSOs, these latter actors still have to include civil society actors in the first place. If they refrain from that, though, even a well-connected country will not consider civil society actors in its delegation, since it will be less concerned then about issues of legitimacy than issues of sovereignty and autonomy. Ultimately, and under those circumstances, it is unlikely that a state will invite civil society groups to its negotiation delegation.

\section{Survey results}

The statistical results show that states more central to the global governance network are more likely to include CSOs if other states do so in the first place. We argued that the underlying causal mechanism is that governments trade additional constraints imposed by CSO inclusion off against legitimacy gains. However, while this is in line with our findings, these results could also point to other mechanisms that cannot be captured with the quantitative methodology and it still remains to be answered empirically whether state actors that formally 
include CSOs really perceive issues of and the tradeoff between sovereignty and legitimacy as important.

Results of a survey we conducted with 50 government representatives from national delegations to the climate CoP in Durban in December 2011 provide additional support for the hypothesized causal mechanism underlying the statistical model results. As in all surveys of this kind, the sample is not entirely random and the respondents occupy differing functions at different levels of hierarchy in national delegations. However, the survey covers a wide range of countries that differ in many ways that are relevant for our purposes: for instance, in terms of income levels (e.g., Tajikistan, Bulgaria, Denmark), the political system (e.g., China, Pakistan, the USA), country size (e.g., Kiribati, Peru, China), geographic location (our sample includes several countries from each continent), and civil society inclusion in a delegation (e.g., Brazil, Libya, Germany). ${ }^{9}$ Moreover, 34 (68\%) of the countries surveyed included CSO representatives in their respective delegation, whereas 16 (32\%) did not. These shares correspond almost exactly to the observed patterns in our data set for the statistical analysis, which covers almost all countries in the UNFCCC process. Hence, we are confident that the responses obtained reflect the dominant views on CSO inclusion among the population of countries in global climate politics. Table 2 gives an overview of the survey's sample.

Table 2 in here

Focusing on the responses from delegates whose delegation included CSO representatives, we obtain additional insights into governmental concerns about constraints and the perceived legitimacy benefits resulting from CSO inclusion. The results are summarized in Figure 2. 14 delegates (42\%) rated as important or very important that CSOs should be able to 'speak on

\footnotetext{
${ }^{9}$ The questionnaire and the survey data can be obtained from the authors upon request.
} 
behalf of the national delegation in the negotiations.' However, 19 delegates (58\%) responded that this function is rather unimportant or not important at all. Further, 26 delegates (81\%) indicated that 'to give interviews to the press on behalf of the government' is not important or not important at all, while six delegates (19\%) regarded this function as important or very important. Having said that, several respondents expressed concerns that CSO representatives, while performing these functions, might take a different position than the one agreed to before the CoP, adopt positions that are not in line with the government's policies, reveal sensitive governmental positions, or act beyond their roles and responsibilities. This evidence supports the constraints part of our argument, which holds that governments trade constraints off against legitimacy gains associated with CSO inclusion.

Figure 2 in here

In terms of the legitimacy issue, more than three quarters of the surveyed government delegates whose national delegation includes CSO representatives $(\mathrm{N}=30 ; 88 \%)$ regarded as important or very important the function of CSO representatives to 'observe the negotiations and report back to the public at home.' Only four respondents (12\%) regarded this function as not important or not important at all. A large majority of 27 government delegates (79\%) agreed or strongly agreed that 'the inclusion of civil society actors in the national delegations makes it easier for the government to convince citizens back home to support the government's position.' Only a small share of respondents $(\mathrm{N}=7 ; 21 \%)$ did not agree with this statement. $^{10}$

\section{Conclusion}

\footnotetext{
${ }^{10}$ A question directly pertaining to the postulated contagion effect would further clarify the underlying issues. However, the original survey did not contain such a question.
} 
In many areas of global governance, civil society participation reached spectacularly high levels. Predominantly in global climate politics, the empirical area our research focused on, around $70 \%$ of all national delegations included at least one CSO representative and $18 \%$ of all members of national delegations at the 2011 UNFCCC CoP were CSO representatives. This means that CSOs are present at a massive scale - not only as observers from the outside, but also formally included as negotiators on the inside.

The theoretical argument developed in this paper focused on social networks and legitimacy in an effort to account for CSO inclusion in global governance. We argued that governments consider both constraints on government behavior and gains in legitimacy when deciding on whether to formally involve CSOs in their delegations or not. When trading these two aspects off, social networks - the network of global IGO memberships as in our case are likely to play an important role in this respect. We claimed that - contingent on their extent of network centrality - governments are more likely to include CSO representatives if other countries do so.

The quantitative analysis offers robust empirical support for this argument. Evidence from a survey conducted with 50 government representatives from national delegations to the 2011 UNFCCC CoP in Durban lines up well with the underlying theoretical assumption that the contagion effect traveling through the global IGO network is driven by government considerations of legitimacy. This finding corresponds to the frequently made argument that civil society constitutes a 'transmission belt' between governments and their domestic citizenry (Steffek \& Nanz 2007: 3).

Further research could expand on the findings of our study in at least four ways. First, more detailed surveys of government representatives are needed to better understand the reasons why CSO representatives are included or not in national delegations. Such surveys should also identify variation across countries with respect to how autonomous included 
CSOs are from the respective government, and what constraints are imposed on CSO representatives within delegations. It would also be interesting to find out whether including CSOs has the presumed legitimacy increasing effect on domestic audiences. If governments are including civil society to achieve legitimacy gains, and if they are taking well-informed decisions in this respect, we should observe that including CSO representatives makes domestic publics more accepting of procedural and perhaps even outcome aspects of global climate governance.

Second, climate policy might be a rather exceptional case in terms of its level of CSO involvement and, thus, our study is unlikely to explain variance across domains, but rather applies to the issue of environmental and climate politics. However, although there is no systematic data that permit comparisons across global policy areas at this point, it might be an effort worth making to study other policy areas such as the security or trade domains based on our theoretical argument and empirical approach.

Third, although we could clarify why states might be more likely to include CSOs in their delegation conditional on their level of connectedness to other states and how these treat civil society, it remains unclear why the latter grant CSOs access in the first place. We found support for the contagion effect, but there must be one country in the first place that makes the decision to formally include civil society in its delegation independent from other states.

Finally, not all civil society groups are created equal and we might want to consider the relations among civil society groups and how they are networked as well. Risse-Kappen (1995), for instance, highlights the importance of internal characteristics such as resources, strategies, and leadership skills in relation to structural factors, e.g., domestic structures and transnational institutions, in influencing the policy impact of civil society groups (see also Sell and Prakash 2004: 169). In other words, it may be worth examining civil society organizations' characteristics, their relations, and their networks more thoroughly than it was 
possible in this study. Due to the current lack of data covering a broad set of actors and years on this, however, more data collection efforts seem necessary to address this issue more effectively (see, e.g., Bernhagen 2013: 36).

In practical policy terms, our results suggest that those interested in increasing civil society involvement in global governance should try and motivate as many states as possible to include CSO representatives in their national delegations. This would facilitate the diffusion of CSO involvement to other countries. Obtaining observer status in global governance fora, which is what most CSOs focus on, hinges on collective inter-governmental decisions to grant access to CSOs. In contrast, each country is free to decide on its own how its national delegation is composed. Civil society involvement could thus be promoted quite effectively via unilateral national steps that have ripple effects through the global governance network. 


\section{References}

Baumgartner, F.R. \& Leech, B.L. (2001). Interest niches and policy bandwagons: Patterns of interest group involvement in national politics. Journal of Politics 63: 1191-1213.

Baumgartner, F.R., Berry, J.M., Hojnacki, M., Kimball, D.C. \& Leech, B.L. (2009). Lobbying and policy change: Who wins, who loses, and why. Chicago, IL: University of Chicago Press.

Beck, N., Katz, J.N. \& Tucker, R. (1998). Taking time seriously: Time-series cross-section analysis with a binary dependent variable. American Journal of Political Science 42: $1260-1288$.

Bernauer, T. \& Betzold, C. (2012). Civil society in global environmental governance. Journal of Environment and Development 21: 62-66.

Bernauer, T., Böhmelt, T. \& Koubi, V. (2013). Is there a democracy-civil society paradox in global environmental governance? Global Environmental Politics: 88-108.

Bernhagen, P. (2013). When do politicians listen to lobbyists (and who benefits when they do)? European Journal of Political Research 52: 20-43.

Bernstein, S. (2005). Legitimacy in global environmental governance. Journal of International Law and International Relations 1: 139-166.

Betsill, M. (2006). Transnational actors in international environmental politics. In M. Betsill, K. Hochstetler \& D. Stevis (eds), Palgrave Advances in International Environmental Politics (pp. 172-202). New York: Palgrave Macmillan.

Betsill, M. \& Corell, E. (eds). (2008). NGO diplomacy: The influence of nongovernmental organizations in international environmental negotiations. Cambridge, MA: MIT Press.

Betsill, M. \& Corell, E. (2001). NGO influence in international environmental negotiations: A framework for analysis. Global Environmental Politics 1: 65-85. 
Biermann, F. \& Gupta, A. (2011). Accountability and legitimacy in earth system governance: A research framework. Ecological Economics 70: 1856-1864.

Biermann, F. \& Pattberg, P. (2008). Global environmental governance: Taking stock, moving forward. Annual Review of Environment and Resources 33: 277-294.

Bodin, Ö. \& Prell, C. (2011). Social networks and natural resource management: Uncovering the social fabric of environmental governance. Cambridge: Cambridge University Press.

Böhmelt, T. (2013). A closer look at the information provision rationale: Civil society participation in states’ delegations at the UNFCCC. Review of International Organizations. Forthcoming.

Borgatti, S.P., Mehra, A., Brass, D.J. \& Labianca, G. (2009). Network analysis in the social sciences. Science 323: 892-895.

Brambor, T., Clark, W.R. \& Golder, M. (2006). Understanding interaction models: Improving empirical analysis. Political Analysis 14: 63-82.

Cao, X. (2010). Networks as channels of policy diffusion: Explaining worldwide changes in capital taxation, 1998-2006. International Studies Quarterly 54: 823-854.

Cao, X. (2009). Networks of intergovernmental organizations and convergence in domestic economic policies. International Studies Quarterly 53: 1095-1130.

Cao, X. \& Prakash, A. (2012). Trade competition and environmental regulations: Domestic political constraints and issue visibility. Journal of Politics 74: 66-82.

Castiglione, D. (1998). Civil society. In P. Newman (ed), The new Palgrave dictionary of economics and the law (pp. 250-267). Basingstoke: MacMillan.

Charnovitz, S. (1997). Two centuries of participation: NGOs and international governance. Michigan Journal of International Law 18: 183-286. 
Clark, A.M., Friedman, E.J. \& Hochstetler, K. (1998). The sovereign limits of global civil society: A comparison of NGO participation in the UN world conference on the environment, human rights, and women. World Politics 51: 1-35.

Clark, J. (1995). The state, popular participation, and the voluntary sector. World Development 23: 593-601.

Congleton, R.D. (1992). Political institutions and pollution control. Review of Economics and Statistics 74: 412-421.

Corell, E. \& Betsill, M. (2001). A comparative look at NGO influence in international environmental negotiations: Desertification and climate change. Global Environmental Politics 1: 86-106.

Dellas, E. (2011). CSD water partnerships: Privatization, participation, and legitimacy. Ecological Economics 70: 1916-1923.

Dombrowski, K. (2010). Filling the gap? An analysis of nongovernmental organizations responses to participation and representation deficits in global climate governance. International Environmental Agreements 10: 397-416.

Dorussen, H. \& Ward, H. (2008). Intergovernmental organizations and the Kantian peace - A network perspective. Journal of Conflict Resolution 52: 189-212.

Dryzek, J.S. 2012. Global civil society: The progress of post-Westphalian politics. Annual Review of Political Science 15: 1-19.

Dryzek, J.S. \& Stevenson, H. (2011). Democracy and global earth system governance. Ecological Economics 70: 1865-1874.

Economy, E. (2004). The river runs black: The environmental challenge to China's future. Ithaca, NY: Cornell University Press.

Freeman, L.C., Borgatti, S.P. \& White, D.R. (1991). Centrality in valued graphs: A measure of betweenness based on network flow. Social Networks 13: 141-154. 
Grant, R.W. \& Keohane, R.O. (2005). Accountability and abuses of power in world politics. American Political Science Review 99: 29-43.

Grossman, G.M. \& Krueger, A.B. (1995). Economic growth and the environment. Quarterly Journal of Economics 110: 353-377.

Gulbrandsen, L.H. (2008). The role of science in environmental governance: Competing knowledge producers in Swedish and Norwegian forestry. Global Environmental Politics 8: 99-122.

Grundbrandsen, L.H. \& Andresen, S. (2004). NGO influence in the implementation of the Kyoto protocol: Compliance, flexibility mechanisms, and sinks. Global Environmental Politics 4: 54-75.

Haas, P.M. (1999). Social constructivism and the evolution of multilateral environmental governance. In A. Prakash \& J.A. Hart (eds), Globalization and governance (pp. 103-133). London: Routledge.

Hafner-Burton, E., Kahler, M. \& Montgomery, A. (2009). Network analysis for international relations. International Organization 63: 559-592.

Hafner-Burton, E. \& Montgomery, A. (2006). Power positions - International organizations, social networks, and conflict. Journal of Conflict Resolution 50: 3-27.

Hafner-Burton, E., von Stein, J. \& Gartzke, E. (2008). International organizations count. Journal of Conflict Resolution 52: 175-188.

Howell, L.D. (2011). International country risk guide methodology. East Syracuse, NY: The PRS Group.

Johnson, E. \& Prakash, A. (2007). NGO research program: A collective action perspective. Policy Sciences 40: 221-240.

Keck, M. \& Sikkink, K. (1998). Activists beyond borders: Advocacy networks in international politics. Ithaca, NY: Cornell University Press. 
Keohane, R.O. (2011). Global governance and legitimacy. Review of International Political Economy 18: 99-109.

King, G., Tomz, M. \& Wittenberg, J. (2000). Making the most of statistical analyses: Improving interpretation and presentation. American Journal of Political Science 44: 347361.

Kingsbury, B. (2007). Global environmental governance as administration: Implications for international law. In D. Bodansky, J. Brunnée \& E. Hey (eds), Oxford handbook of international environmental law (pp. 63-84). Oxford: Oxford University Press.

Leifeld, P. \& Schneider, V. (2012). Information exchange in policy networks. American Journal of Political Science 56: 731-744.

Lipset, S.M. (1983). Political man: The social bases of politics. London: Heinemann.

Maoz, Z. (2010). Networks of nations: The evolution, structure, and impact of international networks, 1816-2001. Cambridge: Cambridge University Press.

Marshall, M.G. \& Jaggers, K. (2002). POLITY IV project: Political regime characteristics and transitions, 1800-2002. Dataset user's manual. College Park, MD: University of Maryland.

Mason, M.R. (2008). The governance of transnational environmental harm: Addressing new modes of accountability/responsibility. Global Environmental Politics 8: 8-24.

Mendelsohn, R., Dinar, A. \& Williams, L. (2006). The distributional impact of climate change on rich and poor countries. Environment and Development Economics 11: 159178.

Nye, J. (2001). Globalization's democratic deficit: How to make international institutions more accountable. Foreign Affairs 80: 2-6.

Paterson, M. (1996). Global warming and global politics. London: Routledge. 
Pevehouse, J.C., Nordstrom, T. \& Warnke, K. (2004). The COW-2 international organizations dataset version 2.0. Conflict Management and Peace Science 21: 101-119.

Putnam, R. (1988). Diplomacy and domestic politics: The logic of two-level games. International Organization 42: 427-460.

Raustiala, K. (1997). States, NGOs, and international environmental institutions. International Studies Quarterly 41: 719-740.

Risse-Kappen, T. (1995). Bringing transnational relations back in. Cambridge: Cambridge University Press.

Ruggie, R. (1986). Continuity and transformation in the world polity: Toward a neorealist synthesis. In R.O.Keohane (ed), Neorealism and its critics (pp. 131-157). New York: Columbia University Press.

Scholte, J.A. (2004). Civil society and democratically accountable global governance. Government and Opposition 39: 211-233.

Schouten, G. \& Glasbergen P. (2011). Creating legitimacy in global private governance. The case of the Roundtable on Sustainable Palm Oil. Ecological Economics 70: 1891-1899.

Seleden, T. \& Song, D. (1994). Environmental quality and development: Is there a Kuznets curve for air pollution emissions? Journal of Environmental Economics and Management 27: $147-162$.

Sell, S.K. \& Prakash, A. (2004). Using ideas strategically: The contest between business and NGO networks in intellectual property rights. International Studies Quarterly 48: 143-175.

Singer, D. (1988). Reconstructing the Correlates of War dataset on material capabilities of states, 1816-1985. International Interactions 14: 115-132.

Stasavage, D. (2004). Open-door or closed-door? Transparency in domestic and international bargaining. International Organization 58: 667-703. 
Steffek, J. \& Ferretti, M.P. (2009). Accountability or good decisions? The competing goals of civil society participation in international governance. Global Society 23: 37-57.

Steffek, J. \& Nanz, P. (2007). Emerging patterns of civil society participation in global and European governance. In J. Steffek, C. Kissling \& P. Nanz (eds), Civil society participation in European and global governance: A cure for the democratic deficit? (pp. 1-29). New York: Palgrave Macmillan.

Thomann, L. (2007). The ILO, tripartism, and NGOs: Do too many cooks really spoil the broth? In J. Steffek, C. Kissling \& P. Nanz (eds), Civil society participation in European and global governance: A cure for the democratic deficit? (pp. 71-94). New York: Palgrave Macmillan.

Torfason, M.T. \& Ingram, P. (2010). The global rise of democracy: A network account. American Sociological Review 75: 355-377.

Vabulas, F. (2011). When and why do intergovernmental organizations grant formal access to NGOs? University of Chicago, IL: Typescript.

von Stein, J. (2008). The international law and politics of climate change. Journal of Conflict Resolution 52: 243-268.

Ward, H. (2006). International linkages and environmental sustainability: The effectiveness of the regime network. Journal of Peace Research 43: 149-166.

Ward, H. (2008). Liberal democracy and sustainability. Environmental Politics 17: 386-409.

Ward, H. \& Cao, X. (2012). Domestic and international influences on green taxation. Comparative Political Studies 45: 1075-1103.

Ward, M.D., Stovel, K. \& Sacks, A. (2011). Network analysis and political science. Annual Review of Political Science 14: 245-264.

Weiss, T.G. \& Gordenker, L. (1996). NGOs, the UN, and global governance. Boulder, CO: Lynne Rienner. 
Table 1. Probit regression models - Main results

\begin{tabular}{|c|c|c|c|}
\hline & Model 1 & Model 2 & Model 3 \\
\hline \multirow[t]{2}{*}{ Civil society - Dyadic counterpart } & -0.024 & & -0.117 \\
\hline & {$[-0.052 ; 0.008]$} & & {$[-0.180 ;-0.042]$} \\
\hline \multirow[t]{2}{*}{ Network centrality } & 0.318 & & 0.246 \\
\hline & {$[0.310 ; 0.328]$} & & {$[0.222 ; 0.271]$} \\
\hline \multirow[t]{2}{*}{ CS - Dyadic counterpart * Netw. centr. } & 0.065 & & 0.196 \\
\hline & {$[0.012 ; 0.123]$} & & {$[0.084 ; 0.300]$} \\
\hline \multirow[t]{2}{*}{ Bureaucratic quality } & & -0.012 & 0.023 \\
\hline & & {$[-0.031 ; 0.007]$} & {$[0.002 ; 0.0 .045]$} \\
\hline \multirow[t]{2}{*}{ Income - GDP per capita (ln) } & & 0.387 & 0.320 \\
\hline & & {$[0.369 ; 0.405]$} & {$[0.297 ; 0.343]$} \\
\hline \multirow[t]{2}{*}{ Democracy } & & 0.202 & 0.195 \\
\hline & & {$[0.194 ; 0.210]$} & {$[0.185 ; 0.204]$} \\
\hline \multirow[t]{2}{*}{ Major power } & & -0.075 & -0.039 \\
\hline & & {$[-0.086 ;-0.065]$} & {$[-0.052 ;-0.025]$} \\
\hline \multirow[t]{2}{*}{ Population (ln) } & & 0.666 & 0.600 \\
\hline & & {$[0.654 ; 0.678]$} & {$[0.584 ; 0.615]$} \\
\hline \multirow[t]{2}{*}{ Domestic civil society leverage } & & -0.174 & -0.192 \\
\hline & & {$[-0.194 ;-0.153]$} & {$[-0.212 ;-0.172]$} \\
\hline \multirow[t]{2}{*}{ Civil society years } & -0.611 & -0.608 & -0.595 \\
\hline & {$[-0.617 ;-0.604]$} & {$[-0.614 ;-0.603]$} & {$[-0.601 ;-0.588]$} \\
\hline \multirow[t]{2}{*}{ Spline 1} & -0.874 & 0.061 & -0.198 \\
\hline & {$[-0.877 ;-0.870]$} & {$[-0.129 ; 0.217]$} & {$[-0.480 ;-0.084]$} \\
\hline \multirow[t]{2}{*}{ Spline 2} & -0.931 & -0.669 & -0.660 \\
\hline & {$[-0.935 ;-0.928]$} & {$[-0.673 ;-0.663]$} & {$[-0.666 ;-0.654]$} \\
\hline \multirow[t]{2}{*}{ Spline 3} & 0.176 & 0.352 & 0.357 \\
\hline & {$[0.173 ; 0.180]$} & {$[0.348 ; 0.357]$} & {$[0.352 ; 0.363]$} \\
\hline Observations & 253,491 & 239,076 & 171,020 \\
\hline Log pseudo likelihood & $-114,488.29$ & $-121,313.94$ & $-86,102.14$ \\
\hline
\end{tabular}

Notes: First difference estimates $(y=1)$ when value of explanatory variable changes from minimum to maximum while holding all other variables at their median values. Estimates are based on simulations ( $N=1,000$ of random draws for simulated parameters). $95 \%$ confidence interval is in brackets. Underlying robust standard errors are clustered on undirected dyad. 
Table 2. Overview of survey sample

\begin{tabular}{|c|c|}
\hline Official representative from which country? & Does country delegation have civil society members? \\
\hline Angola & Yes \\
\hline Bangladesh & Yes \\
\hline Belgium & Yes \\
\hline Belgium & Yes \\
\hline Bhutan & Yes \\
\hline Bulgaria & Yes \\
\hline Cameroon & No \\
\hline Canada & Yes \\
\hline China & Yes \\
\hline Colombia & No \\
\hline Croatia & Yes \\
\hline Cyprus & Yes \\
\hline Czech Republic & No \\
\hline Denmark & No \\
\hline Ethiopia & Yes \\
\hline Germany & No \\
\hline Greece & No \\
\hline Grenada & Yes \\
\hline Indonesia & Yes \\
\hline Iraq & No \\
\hline Japan & Yes \\
\hline Kazakhstan & Yes \\
\hline Kenya & Yes \\
\hline Kiribati & Yes \\
\hline Libya & Yes \\
\hline Mauritania & Yes \\
\hline Montenegro & No \\
\hline Mozambique & Yes \\
\hline Namibia & Yes \\
\hline Netherlands & No \\
\hline New Zealand & Yes \\
\hline Norway & Yes \\
\hline Pakistan & Yes \\
\hline Paraguay & Yes \\
\hline Peru & No \\
\hline Philippines & Yes \\
\hline Poland & No \\
\hline Russia & Yes \\
\hline Senegal & No \\
\hline Somalia & Yes \\
\hline Spain & No \\
\hline Tajikistan & No \\
\hline Tanzania & Yes \\
\hline Thailand & Yes \\
\hline Turkey & Yes \\
\hline Tuvalu & Yes \\
\hline Uganda & Yes \\
\hline Ukraine & Yes \\
\hline United Kingdom & No \\
\hline United States of America & No \\
\hline
\end{tabular}


Figure 1. Interaction effect of Network centrality and Civil society - Dyadic counterpart
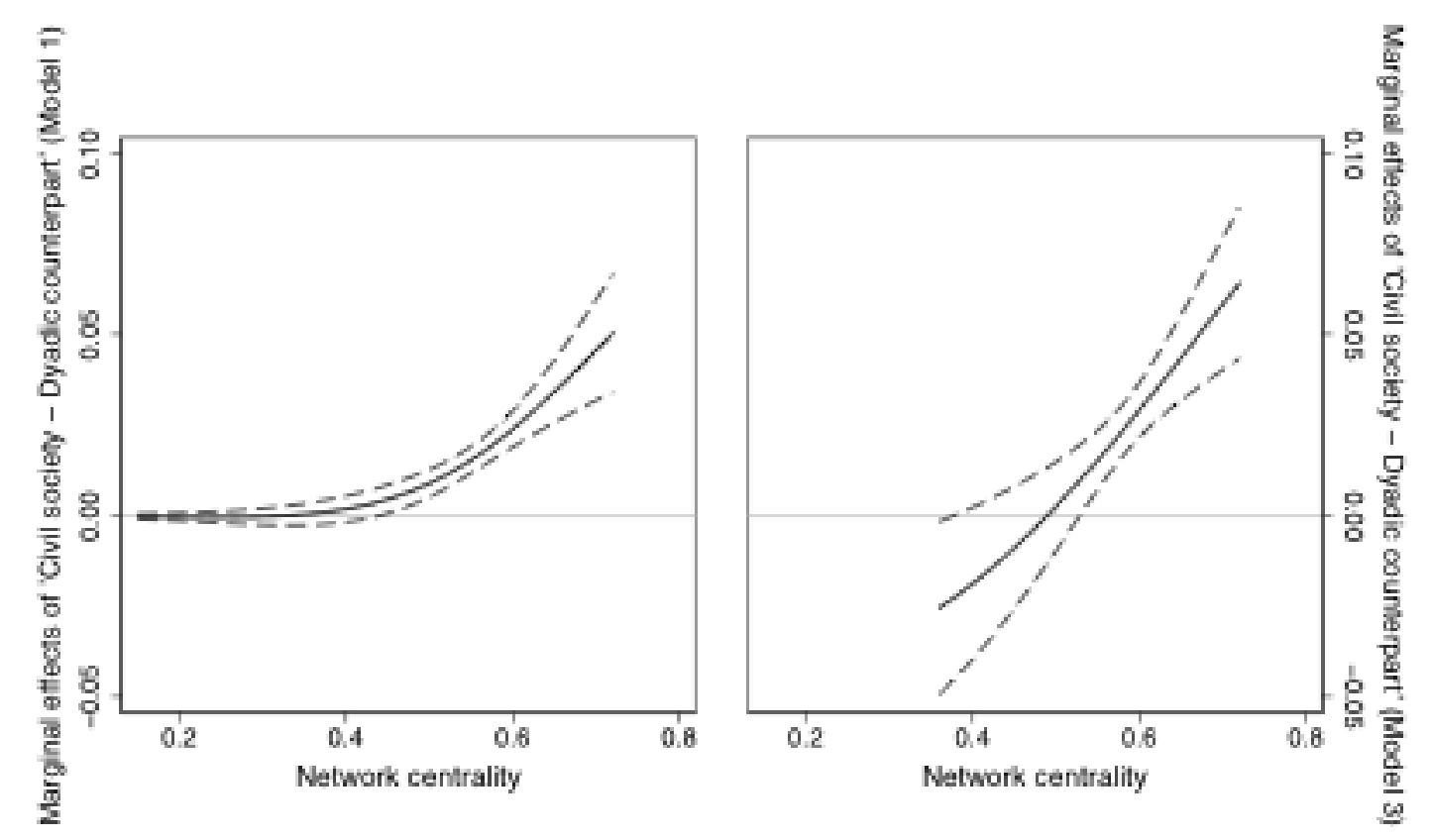

Notes: Left panel is based on Model 1. Right panel is based on Model 3. Dashed lines indicate 95\% confidence interval. Solid horizontal line marks marginal effect of 0 . 
Figure 2. Core results from survey: The importance of sovereignty and legitimacy
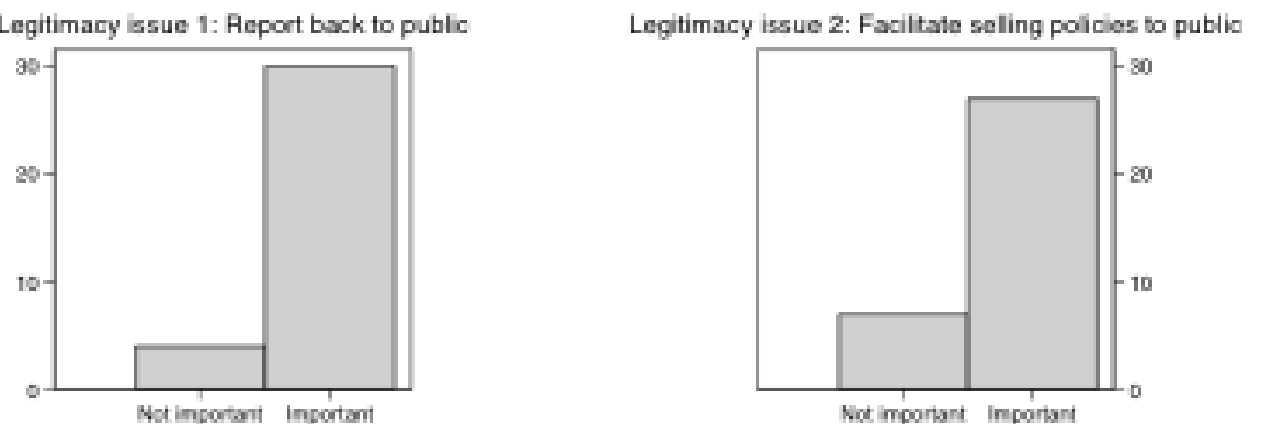

Sowereignty issue 1: Spesk on beharf of delegation

Sovereignty isgue 2: Interviews to press on behalf of delegation
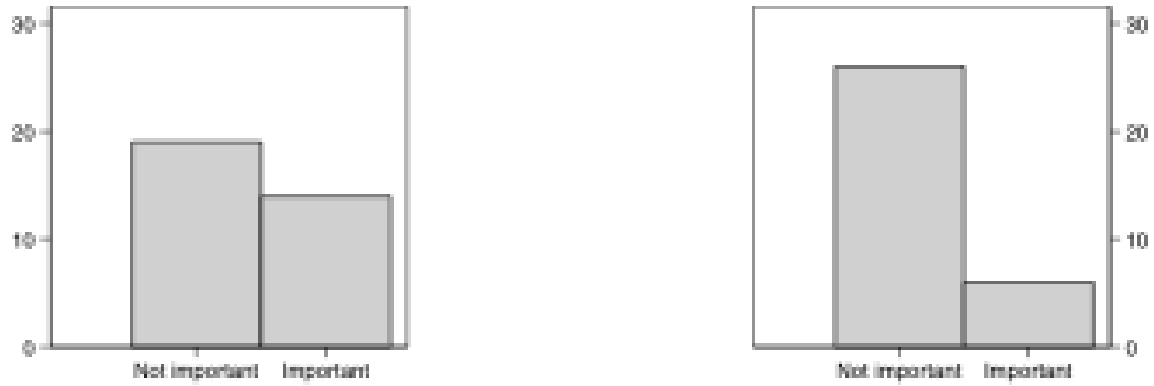


\section{Appendix}

\section{Descriptive statistics}

Table 1 of this appendix summarizes the descriptive statistics for all explanatory and control variables used for our analysis. The variation inflation factors (VIFs) indicate that the simultaneous inclusion of these variables is unproblematic from the viewpoint of potential multicollinearity: perhaps contrary to what one might suspect, there is not much overlap between, for example, democratic regimes and the bureaucratic quality of countries.

Appendix table 1. Descriptive statistics

\begin{tabular}{lcccccc}
\hline & Observations & Mean & SD & Min & Max & VIF \\
\hline Civil society inclusion & 354,547 & 0.26 & 0.44 & 0 & 1 & \\
Civil society - Dyadic counterpart & 341,971 & 0.25 & 0.43 & 0 & 1 & 1.00 \\
Network centrality & 429,088 & 0.53 & 0.11 & 0.03 & 0.72 & 1.39 \\
Bureaucratic quality & 329,882 & 2.19 & 1.15 & 0 & 4 & 3.27 \\
Income - GDP per capita (ln) & 449,567 & 7.75 & 1.64 & 4.16 & 11.79 & 3.51 \\
Democracy & 416,779 & 3.17 & 6.70 & -10 & 10 & 1.40 \\
Major power & 466,144 & 0.04 & 0.19 & 0 & 1 & 1.59 \\
Population (ln) & 461,978 & 15.43 & 2.14 & 9.15 & 20.99 & 1.93 \\
Domestic civil society leverage & 347,500 & 4.74 & 7.02 & 0 & 54 & 1.87 \\
\hline
\end{tabular}

Notes: Interaction term and variables for temporal correction omitted from table.

\section{Robustness checks}

The results reported in the main article are robust to a wide range of alternative model specifications. First, Clarke (2005) shows that the inclusion of control variables may actually increase the likelihood of obtaining biased estimates, rather than decreasing it. Some control variables we use may thus artificially reduce the observable effect of our two main explanatory variables and their interaction term. Model 1 in the main text does not include any control variables and still confirms our main results, though.

Second, the table above suggests that the formal inclusion of representatives of civil society organizations in national delegations is quite rare: only $26 \%$ of our 354,547 
observations actually see the onset of CSO participation in national delegations. Thus, we followed King \& Zeng (2001) and corrected the intercept estimate via a rare-events logistic regression model. The main findings are not affected by this change of statistical procedure.

Third, we used three-stage least squares regressions (3SLS) to investigate whether our results might suffer from simultaneity and selection bias. For instance, our estimates of Network centrality could be biased due to self-selection of countries into intergovernmental organizations (see, e.g., Ringquist \& Kostadinova 2005). Also, states that care about legitimacy might be the ones that invest more in network centrality. Hence, our findings could be driven by an underlying commitment to legitimacy that explains both network centrality and the inclusion of civil society organizations but not by network centrality. For specifying the 3SLS, we treat Civil society inclusion and Network centrality as endogenous variables accordingly. While the results are very similar to those shown in Table 1 of the main text, it is worth noting that Network centrality still has a positive effect that is significant at the $1 \%$ level, but the impact of Civil society inclusion is also significant. This result supports the conclusion that the causal effect runs from network centrality to Civil society inclusion - and the other way. However, and as emphasized, our core results remain unchanged.

Fourth, an anonymous reviewer raised the concern that the binary operationalization of our dependent variable might be inappropriate and suggested instead a count item capturing the number of civil society actors as part of state delegations. The original rationale behind the binary operationalization was twofold. First, the binary variable taken from Böhmelt (2013) does not suffer from missing values. However, the count item lacks information for some state delegations. Second, a dichotomous operationalization employs a somewhat conservative approach, which ensures that we do not overestimate the impact on the inclusion of civil society organizations in a delegation. That being said, we re-estimated all models with a count item instead, using a negative binomial regression model that follows the 
specifications of Model 3 in Table 1 of the main text. The results from the negative binomial regression essentially mirror this Model 3 that employs the binary dependent variable. The substantive quantity of interest is summarized in the figure below.

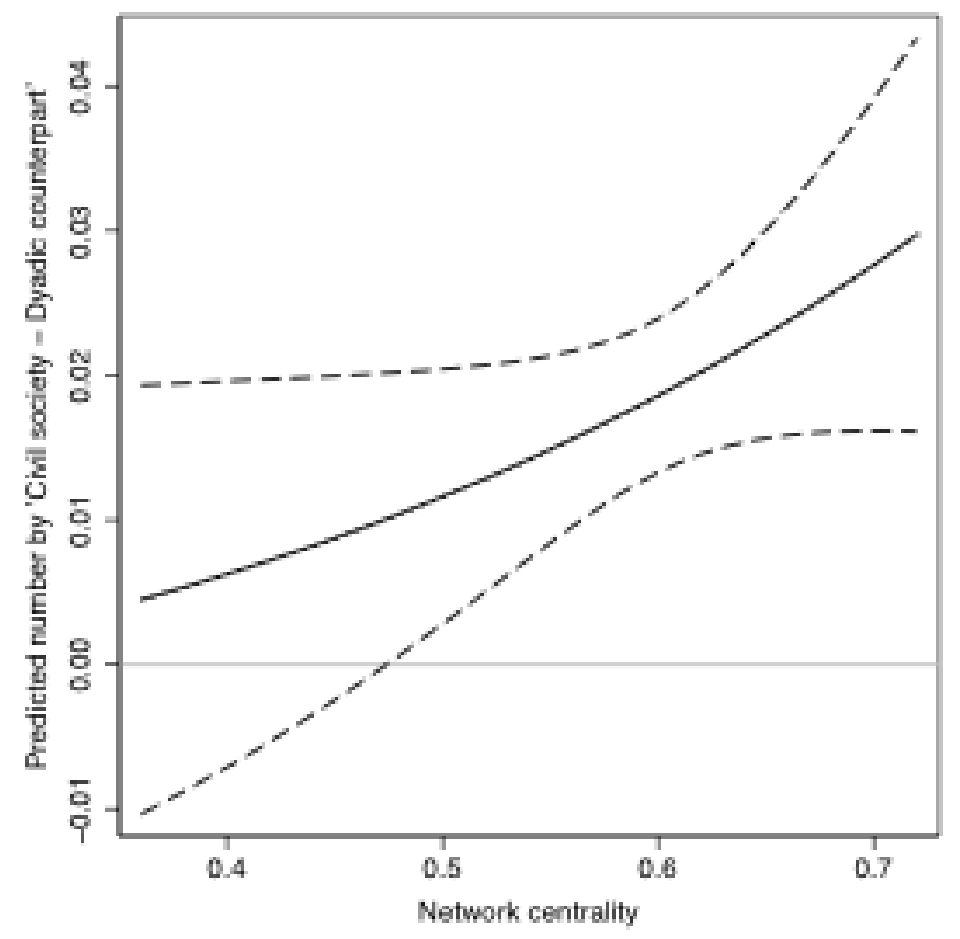

Appendix figure 1. Interaction effect of Network centrality and Civil society - Dyadic counterpart based on the negative binomial regression model.

Notes: Dashed lines indicate 95\% confidence interval.

Finally, our approach for the interaction between Civil society - Dyadic counterpart and Network centrality essentially follows the logic of spatial lag models, i.e., to capture policy interdependencies (e.g., Franzese \& Hays 2007; Cao 2010: 833; Cao \& Prakash 2012: 75; Ward \& Cao 2012). As a final robustness check, we thus estimated such a model that has the simplified form of:

$$
y_{t}=X_{t} \beta+\rho W y_{t-1}
$$

where $y_{t}$ constitutes our dependent variable, $X$ pertains to the set of control variables and the constant, and $W y_{t-1}$ signifies the product of the row-standardized connectivity matrix $(W)$ and 
the dependent variable lagged by one year $\left(y_{t-1}\right)$, i.e., $W y_{t-1}$ is the spatial lag. In the words of Ward \& Cao (2012: 1084), 'the connectivity matrix, $W$, is $N T x N T$ matrix with $T N x N$ submatrices along the block diagonal, and typical element $w_{i, j, t}$ capturing relative connectivity or influence from unit $j$ to $i$ at time $t$.' The spatial lag 'gives a weighted average of other observations in the year concerned, with each weight specified by $w_{i, j, t}$. The estimation of $\rho$ (spatial coefficient) captures the strength of policy interdependence'. We row standardized the connectivity matrix so that the estimated values of $\rho$ reflect the average influence of other countries' behavior toward civil society organizations (excluding a respective country under study).

However, in order to avoid simultaneity bias, we employed a lagged version of the dependent variable in order to calculate the spatial lag (Franzese \& Hays 2007), i.e., the spatial lag does not give a weighted average of other observations in the year concerned, but in the previous year. Following our theoretical rationale, higher levels of policy interdependence and mutual influence regarding the inclusion of civil society organizations in delegations should be given for states that are more strongly connected to each other. We measured the degree of connectedness between two states via their co-affiliation to intergovernmental organizations, i.e., each element $w_{i, j, t}$ in the connectivity matrix is the number of common memberships in intergovernmental organizations shared by country $i$ and country $j$. The data for this are taken from the same source we used for Network centrality in the main article, while we transformed our data set into a monadic version that has the country-year as the unit of analysis. We expected a positive spatial coefficient $\rho$ and, in fact, the unreported estimation of a probit regression model that substitutes Civil society - Dyadic counterpart, Network centrality, and their interaction term for the spatial lag supports this. More specifically, when moving from the minimum to the maximum of $W y_{t-1}$, the probability of a country including civil society organizations increases by about $42 \%$. Hence, this 
basically mirrors our findings reported in the main text as it is suggested that countries strongly linked via intergovernmental organizations influence each other's behavior towards civil society organizations.

\section{References of appendix}

Böhmelt, T. (2013). A closer look at the information provision rationale: Civil society participation in states’ delegations at the UNFCCC. Review of International Organizations. Forthcoming.

Cao, X. (2010). Networks as channels of policy diffusion: Explaining worldwide changes in capital taxation, 1998-2006. International Studies Quarterly 54: 823-854.

Cao, X. \& Prakash, A. (2012). Trade competition and environmental regulations: Domestic political constraints and issue visibility. Journal of Politics 74: 66-82.

Clarke, K.A. (2005). The phantom menace: Omitted variable bias in econometric research. Conflict Management and Peace Science 22: 341-352.

Franzese, R.J. \& Hays, J.C. (2007). Spatial econometric models of cross-sectional interdependence in political science panel and time-series-cross-section data. Political Analysis 15: 140-164.

King, G. \& Zeng, L. (2001). Logistic regression in rare events data. Political Analysis 9: 13763.

Ringquist, E.J. \& Kostadinova, T. (2005). Assessing the effectiveness of international environmental agreements: The case of the 1985 Helsinki protocol. American Journal of Political Science 49: 86-102.

Ward, H. \& Cao, X. (2012). Domestic and international influences on green taxation. Comparative Political Studies 45: 1075-1103. 